ET

60,2

Received 25 June 2017

Revised 1 December 2017

Accepted 1 December 2017

\section{Teaching a sense of initiative and entrepreneurship with constructive alignment in tertiary non-business contexts}

\author{
Daniele Morselli \\ Faculty of Educational Sciences, \\ University of Helsinki, Helsinki, Finland
}

\begin{abstract}
Purpose - The purpose of this paper is to focus on a course in entrepreneurship education for students studying for a Masters in Educational Sciences at a Finnish university. The course was structured around the principles of constructive alignment and aimed to move beyond reflection on entrepreneurship towards action Design/methodology/approach - The course was delivered in alignment with intended learning outcomes, teaching and learning activities, and assessment. Along with lectures, group work and peer-review activities, students prepared a career development plan as the course progressed, undertook a homework assignment, wrote a reflective journal, and sat the GET2 test twice.

Findings - Quantitative and qualitative analysis suggests that students developed more enterprising attitudes as result of participating in the course. This paper makes an argument in favour of entrepreneurship as a subject for all, a transformative experience capable of shaping the mindset in all who participate.

Originality/value - This paper shows how a course on entrepreneurial education based on a "through" approach can be taught at a tertiary level in places other than economics faculties or business schools. Most tertiary courses rely on "about" and "for" approaches to entrepreneurial education, are teacher-centred, and follow a behaviouristic or cognitive learning paradigm of knowledge transmission, as opposed to the student-centred constructivist approach deployed and described here.
\end{abstract}

Keywords Entrepreneurial education, Lifelong learning, Sense of initiative and entrepreneurship, Constructive alignment, General enterprising test, University pedagogy

Paper type Case study

\section{Introduction}

Over recent decades, entrepreneurial education in higher education has been one of the fastestgrowing topics on both sides of the Atlantic (Kyrö and Carrier, 2005). Most commentators now agree that it is time to move beyond the traditional business school model (Béchard and Grégoire, 2005; Gibb, 2002; Jones et al., 2014; Sarasvathy and Vankataraman, 2011), and that entrepreneurial education must make use of both innovative and student-centred pedagogies if it wishes to promote an entrepreneurial mindset (Fiet 2001; Hytti and O'Gorman, 2004; Jones and Iredale, 2014; Kyrö and Carrier, 2005; Solomon, 2007).

However, it appears that traditional teaching methods remain dominant in tertiary entrepreneurial programmes (Solomon, 2007; Kyrö and Carrier, 2005; Blenker et al., 2011). These pedagogies are often based on mere transmission of knowledge (Kyrö and Carrier, 2005), which stultifies the shaping of an entrepreneurial mindset (Kirby, 2004). In other words, in tertiary contexts there has been a lack of coherence between traditional teaching approaches and expected learning outcomes (Mwasalwiba, 2010; Kyrö, 2005). One of the

(c) Daniele Morselli. Published in Education + Training. Published by Emerald Publishing Limited. This article is published under the Creative Commons Attribution (CC BY 4.0) licence. Anyone may reproduce, distribute, translate and create derivative works of this article (for both commercial and non-commercial purposes), subject to full attribution to the original publication and authors. The full terms of this licence may be seen at http://creativecommons.org/licences/by/4.0/legalcode 
factors in scholars' difficulty in framing entrepreneurial education is that ideas have tended to be taken from the field of entrepreneurship rather than that of education (Fayolle and Gailly, 2008; Fayolle, 2013; Jones et al., 2014; Kyrö, 2015), which has meant research on entrepreneurial education has often avoided justifying the educational choices made (Béchard and Grégoire, 2005). It is necessary therefore to clarify philosophical approaches to teaching, and to the role of teachers and learners in entrepreneurial education (Fayolle and Gailly, 2008), transcending "taken-for-granted" assumptions (Fayolle, 2013).

The theory of constructive alignment is one of the most established theories of curriculum in tertiary educational settings, and it has been implemented on a large scale with some success (Biggs, 2014). Although constructive alignment has been suggested as appropriate for entrepreneurial education both by scholars (Béchard and Grégoire, 2005; Lackeus, 2015; Mwasalwiba, 2010; Penaluna and Penaluna, 2015) and by national agencies such as the UK Quality Assurance Agency (QAA) (2012), it has never been the specific focus of entrepreneurial education research (Macht and Ball, 2016). This paper seeks to fills that gap, and examines a course dealing with the sense of initiative and entrepreneurship, one of the key European competences for lifelong learning (European Commission, 2007), in an Educational Sciences faculty. The course was delivered using a "through" approach to entrepreneurial education and on the basis of a student-centred pedagogy, namely the theory of constructive alignment. This paper analyses both the intended and non-intended learning outcomes of the course, on a qualitative basis, using student feedback delivered in the form of a reflective journal, and on a quantitative basis, using the results of a general enterprising tendency test administered at the beginning and at the end of the course.

The paper begins by defining its terms, namely enterprise, entrepreneurship and entrepreneurial education. To improve the way in which entrepreneurial education is framed and to go beyond "taken-for-granted assumptions", which have often affected entrepreneurial education teaching (Fayolle, 2013), it examines the differences between traditional and innovative teaching methods (also called teacher-centred and student-centred approaches) and the diverse learning paradigms that they are based on. The paper then gives an overview of the theory of constructive alignment, and introduces the General Enterprising Tendency test (GET2). Following on from this, it presents an in-depth case study, namely a course in entrepreneurial education for masters' students in education, delivered in autumn 2016 at a major Finnish university. The course was designed according to Biggs' (2014) theory of tertiary curriculum, aligning: intended learning outcomes, with verbs taken from the SOLO taxonomy; teaching and learning activities, with group work and real tasks; and evaluation, with rubrics and criteria connected to intended learning outcomes. The paper then considers the results of the GET2 test administered at the beginning and at the end of the course, and presents qualitative analysis of students' feedback on the course. The theory of constructive alignment is used as a framework for the consideration of results, including learning outcomes, teaching and learning activities, and reflection.

\section{Literature review}

\section{Entrepreneurial education}

Entrepreneurship education and enterprise education are often discussed under the umbrella term of entrepreneurship, which gives rise to a misunderstanding of the term (Lackeus, 2015; Mwasalwiba, 2010; Jones and Iredale, 2014). In the UK, enterprise education and entrepreneurship education are two separate forms of education. While enterprise education is the process of giving students an increased ability to generate ideas, and the skills to put them into practice, entrepreneurship education provides students with the further knowledge, capabilities and attributes required to start a new venture or business (QAA, 2012). It is also important to note that enterprise education aims to create an enterprising mindset, on which more specific entrepreneurship education programs can 
ET

60,2

124

then build. This represents a basic progression model, which could overcome the diverse definitions of entrepreneurship, different learning outcomes and disparate teaching methods in entrepreneurial education (Blenker et al., 2011; Lackeus, 2015; Rasmussen and Nybye, 2013). Lackeus (2015) has proposed entrepreneurial education as general term that embeds both entrepreneurship and enterprise education. Similarly to the UK, the promotion and development of entrepreneurial education has been a policy objective in continental Europe for many years, but unlike in the UK, enterprise and entrepreneurship education are not distinct forms of education. At the European level, entrepreneurship is a key competence for lifelong learning, in the form of the sense of initiative and entrepreneurship, which is defined as the ability to turn ideas into actions (European Commission, 2007), terminology very similar to the UK definition of enterprise education.

Research recognises that entrepreneurial education has a range of objectives (Hytti and O'Gorman, 2004). A first objective is the development of a broad understanding of entrepreneurship, and of the role of the entrepreneur in modern societies and economies. This is an "about" approach and is theoretical and content driven in nature (Gibb, 2002; Pittaway and Edwards, 2012). Another objective is to demonstrate entrepreneurialism by taking responsibility for one's own life and career and by playing an active role in value creation in existing organisations and professions (Hytti and O'Gorman, 2004). This "through" approach is process based and experiential, and one whereby learners experience real entrepreneurial learning (Lackeus, 2015; Kyrö, 2005; Pittaway and Edwards, 2012). A third objective of entrepreneurial education is to become an entrepreneur and start a business (Hytti and O'Gorman, 2004). This is a "for" approach, aiming to give budding entrepreneurs the required knowledge and skills (Gibb, 2002; Pittaway and Edwards, 2012).

Jones et al. (2012) wondered if entrepreneurial education in higher education should be available to all students or only to some. The authors consequently envisage four scenarios: entrepreneurship as a subject for all, a transformative experience capable of shaping an entrepreneurial mindset; entrepreneurship as a pathway to support business start-ups with the specific skills necessary to doing so; entrepreneurship as skills and competence for arts' students who intend to commercialise their intellectual property; entrepreneurship as a standalone subject taught in business schools alongside economics, finance and marketing. The four scenarios are highly dependent on the institution delivering the subject, and there is therefore no ready-made solution. The authors conclude that the best solution would be for entrepreneurial education to be shared across the university rather than owned by a single school or faculty, and that this would be technically difficult to achieve.

\section{Traditional and innovative pedagogies in entrepreneurial education}

Different objectives in entrepreneurial education call for different teaching methods (Hytti and O'Gorman, 2004; Fayolle and Gailly, 2008; Mwasalwiba, 2010). In his review of 21 articles dealing with entrepreneurial education, Mwasalwiba (2010) concluded that most researchers simply divide teaching methods into two categories: traditional methods (including lectures) typical of conventional education, and innovative methods (more action based) typical of entrepreneurial education. However, this distinction tends to disregard the century-long debate between traditional and progressive education (Lackeus, 2015) and is therefore not useful when it comes to considering the pedagogies needed for entrepreneurial education (Kyrö, 2015).

For Kyrö $(2005,2015)$ and Béchard and Grégoire (2005), there is a close relationship between learning paradigms in psychology and teaching methods in entrepreneurial education. Similarly, in educational research, Biggs (2012) suggested that it is reasonable to turn to the psychology of learning when devising a technology of teaching. Kyrö (2015) defined learning paradigms as conceptual world views, namely what society thinks is important for its success. A learning paradigm contains the theoretical basis that defines the intrinsic nature of a phenomenon, along with the rules for gaining knowledge of it 
(Kyrö, 2005); the paradigms in psychology that have informed teaching practices are behaviourism, cognitivism and constructivism. These each have their time and place in history; each represents diverse ontological, epistemological and axiological assumptions, and consequently underpins distinct teaching and learning practices (Kyrö, 2015).

For behaviourism the learner is an object to be controlled, and learning is the sum of reactions to external stimuli (Kyrö, 2015). Formal learning is then delivered by means of lectures in classrooms in the context of a learning environment that focuses on reproduction rather than reflection. The teacher knows what has to be learned and how learning should take place. Behaviourism has been often criticised for advocating a mechanistic view of the learning process and a view of learners as being passive and extrinsically motivated, for example by grades (Robinson et al., 2016). The cognitive paradigm is drawn from rationalism and posits that knowledge can be attained by means of reasoning or intellectual intuition (Kyrö, 2005). The knower is an isolated, rational thinker. While behaviourism posits that learning happens outside the individual, for cognitivism learning takes place inside the individual, its main operation being memorising as much information as possible. Consequently, the teacher knows what the right knowledge is to impart, and his or her aim is to transmit as much information as possible (Kyrö, 2015).

Constructivism is the most recent learning paradigm of the three. In the constructivist paradigm information is not simply transferred, but is the result of activities undertaken by learners (Glaser, 1991). Information is chosen and interpreted by the individual, who constructs new knowledge based on prior experience. The learning process here is situational and connected to the culture in which the individual lives. In social constructivism, people construct their social reality in interaction with others. Learning requires self-regulation and the construction of conceptual structures through abstraction and reflection (von Glasersfeld, 1995). The teacher helps the learning process by creating resources and the context for learning (Kyrö, 2005).

Returning to entrepreneurial education, since its early days entrepreneurship has considered the individual to be a unique, risk taking, creative and innovative, free and responsible actor (Kyrö, 2005, 2015). Comparing these characteristics with the three learning paradigms, Kyrö concluded that social constructivism was the only paradigm to incorporate these traits. Nevertheless, behaviourism and cognitivism have been the traditional, student-centred approaches deployed in tertiary contexts to exert strict control over classroom learning (Robinson et al., 2016). In the case of assessment, for example, in recent years education has favoured behaviouristic outcomes because they are predetermined, comparable and easy to measure (Baartman et al., 2007; Lackeus 2015; Penaluna and Penaluna, 2015), at the expense of contextualised learning, which is more suitable for entrepreneurial education (Penaluna and Penaluna, 2015). Learning has been considered little more than remembering, and de-subjectivised and de-contextualised learning has prevailed. Consequently, entrepreneurial education courses have tended to be based on "about" and "for" approaches, privileging transmission of knowledge (Robinson et al., 2016).

By contrast, some scholars (Jones et al., 2014; Penaluna and Penaluna, 2015) suggest a switch from pedagogy to andragogy and heutagogy. While in pedagogy learning tasks are defined by the teacher, in andragogy control is shared and the student retains a degree of self-determination. This is vital for the development of individuals who can act confidently in situations of risk and ambiguity. Students know that they are working in a context that emphasises innovation rather than implementation and that they will be evaluated on this basis. Hytti and O'Gorman (2004) found that a key ingredient of successful entrepreneurial programs was for the teacher to act as a coach and to leave students the freedom to choose how to solve the problems they faced. Andragogy is characterised by: a readiness to learn, a self-directing concept of self, a performance-centred attitude to learning and the use of experience (Forrest and Peterson, 2006). For Sagar (2015), students should participate in the design, delivery and
Teaching a sense of initiative 
ET

60,2

assessment of entrepreneurial education activities, with their learning being constantly monitored, discussed and improved. Heutagogy takes andragogy a step further, since it seeks to shape highly autonomous self-determined learners (Penaluna and Penaluna, 2015). The learner is independent and self-determined; he or she can look for guidance and negotiate access to learning resources as and when appropriate (Jones et al., 2014).

\section{The theory of constructive alignment}

Constructive alignment is a theoretical model that teachers can use at a practical level in curriculum planning to support deep, constructive learning (Biggs and Tang, 2011). For Biggs (2012), there are two important learning theories within student-centred pedagogies, specifically constructivism and phenomenography. While there are differences between the two, Biggs's assumption is that the best way to help educators improve their teaching is to make use of a theory that helps them reflect on what they are doing. While some teachers focus on who their students are, and others on their own activities as teachers, the theory of constructive alignment argues for a focus on what the students do (Biggs and Tang, 2011). Biggs (2003) defined the theory of constructive alignment as "an approach to curriculum design optimising the conditions for quality learning" (p. 1). Constructive signifies that meaning is not transmitted by the teacher, but built by the learner. The teacher supports and encourages the students to construct their own knowledge inside and outside the classroom by means of appropriate learning activities (Wang et al., 2013). Alignment refers to the ways teachers can create an environment that will support learning activities to enable learners to reach the desired learning outcomes (Biggs, 2012). In this kind of learning environment, there is a correspondence between intended learning outcomes, teaching and learning activities, and assessment tasks. Intended learning outcomes are not written in terms of knowledge to be acquired, but rather in terms of the levels of understanding we want the student to achieve (Biggs and Tang, 2011). Wang et al. (2013) compared two courses with different degrees of alignment and concluded that aligned teaching and learning promotes deeper learning.

Implicitly (Mwasalwiba, 2010; Béchard and Grégoire, 2005) or explicitly (Lackeus, 2015; Penaluna and Penaluna, 2015), scholars and national agencies such as the QAA (2012) have suggested that entrepreneurial education courses should be designed to be constructively aligned. For Macht and Ball (2016), the student-centred concept of constructivism is important enough to make constructive alignment a quasi-meta-framework for entrepreneurial education.

\section{The general enterprising tendency test}

The General Enterprising Tendency Test (GET2, openly available at http://get2test.net) was developed by Sally Caird in the 1990s at the University of Durham in the UK. It seeks to evaluate individuals' enterprising potential, defined as the propensity to start up and manage projects. For Caird (1990) anyone can be enterprising, not just entrepreneurs, for example people working within organisations, or volunteers setting up and leading projects in their community. The aims of entrepreneurial education range from development of entrepreneurs to acquisition of life and work skills. The GET2 test is available online, but was in this case taken by students in a paper and pencil format. It is composed of 54 questions grouped under five key characteristics: self-realisation, autonomy, creativity, taking calculated risks and locus of control (Stormer et al., 1999). The reader is asked to agree or disagree with statements such as "I like challenges that stretch my abilities and get bored with things I can do quite easily" or "I would prefer to have a moderate income in a secure job rather than a high income in a job that depended on my performance". Cromie (2000) perceived that entrepreneurial literature has been widely used in developing the instrument, and concluded that the GET2 is comprehensive, accessible, and easy to administer and score. Tested on different occupational groups the GET2 found a meaningful difference between business owners and other groups such as teachers, nurses and civil servants (Caird, 1991). 


\section{Method}

A course dealing with the sense of initiative and entrepreneurship was negotiated with the Faculty of Education at a major Finnish university. It was the first time this university had offered a course in entrepreneurial education tailored specifically to Masters-level education students. Although the course was focused on the sense of initiative and entrepreneurship, the title of the course was simply entrepreneurship education. The five-credit course was taught in English and delivered between October and December 2016 in seven lessons, each two hours in length, to 28 Masters-level education students, 5 exchange students and $2 \mathrm{PhD}$ students. Of the 35 participants selected from 64 enrolments, 30 completed the course and 29 took for the GET2 test in paper and pencil form both at the beginning and at the end of the course. The test was administered in the original English version.

Deployment of constructive alignment entails four steps (Biggs, 2014; Biggs and Tang, 2011):

(1) description of intended course learning outcomes in the form of a verb and its object (content);

(2) creation of a learning environment, and teaching and learning activities, which ask students to address the verb, thus (it is hoped) triggering the expected outcome;

(3) use of assessment tasks containing the same verbs. With the help of rubrics and criteria, it should be possible to make a judgement on how well students' performance has met the learning outcomes; and

(4) transformation of such judgment into final grades.

(1) The expected learning outcomes of the course for learners were as follows:

- to be able to explain the importance of a sense of initiative and entrepreneurship;

- to apply entrepreneurship to their own schools and life as part of their lifelong learning; and

- to reflect on their own entrepreneurial attitudes as part of their lifelong learning.

The verbs to explain, to apply and to reflect were taken from the highest levels of the SOLO taxonomy to promote a deep approach to learning. The learning outcomes were shared with the class on the first day of the course, and were available in the course outline document on the Moodle platform:

(2) Teaching and learning activities engaged with the verbs set out in the intended learning outcomes. The teaching methods I used in class were lectures, group work and peer review. To introduce the topic I made use of short lectures, videos and an expert in entrepreneurial education. These sessions focused on the key competence of the sense of initiative and entrepreneurship, effectuation theory and the entrepreneurial method; the locus of control, creativity and risk taking. Most of the classes, however, were devoted to group work. I divided the students into groups of five depending on the homework assignment selected. The groups discussed how to structure the assignments, for example the headings of their career development plans, and then peer reviewed them before they were submitted. To encourage autonomy and initiative, groups were free to structure their homework assignments and career development plans as they pleased.

The course assignments were:

- A career development plan, where students focused on their future and wrote about their goals in the short, medium and long term, thus preparing for any actions required.
Teaching a sense of initiative 
ET

60,2

- A homework assignment comprising one of the following practical tasks: following an entrepreneur and observing their behaviour in a work context; being alert to surroundings, for example by discovering or identifying new opportunities to be exploited during their studies; adding value to something, for example by changing it.

- A reflective journal where students regularly wrote down their reflections on the development of their sense of initiative and entrepreneurship, focusing particularly on risk taking, creativity, autonomy and self-confidence.

All materials (the course overview, literature on entrepreneurship, GET2 test, and group discussion forums) could be accessed via Moodle.

(3) Assessment was both formative and summative. The GET2 test was offered to students as a formative tool to assess their enterprising attitudes. It helped them reflect on the changes that might occur during the course. The GET2 test also represented a proxy measure of how far the students' sense of initiative and entrepreneurship developed over the course. The other formative evaluation tool was peer review of assignments, which ensured that every essay received comments from two peers.

The career development plan, homework assignment and reflective diary acted as summative evaluation, and were assessed with rubrics that used the same verbs and keywords as the learning outcomes. To take an example, one of the criteria used to assess homework assignments was "consistency of homework assignment with a sense of initiative and entrepreneurship", and in the reflective journal, "connection between reflections and a sense of initiative and entrepreneurship". Each rubric comprised three criteria rated from 0 to 5 , as shown in the example below. Rubrics were shared with students and published on Moodle. Table AI shows one of the rubrics by way of example.

(4) Transformation of judgements into final grades (/100) and averages (1/3 for each assignment) was done by Moodle.

The positioning of the researcher (Ravitch and Carl, 2015) clearly needs to be considered in relation to this methodology, since the methodology is intrinsically interpretative, and the researcher was the expert when it came to delivery. For this reason, this paper recommends the use of case studies in entrepreneurial education (Blenker et al., 2014) because: the researcher retains the meaningful and holistic features of real-life events while dealing with the complexity of social phenomena; with a commitment to robustness, richness and depth in research and findings, the process is just as important as any result; case studies correlate qualitative with quantitative data. I further ensured the trustworthiness of my research, and the rigour and quality of the study (Ravitch and Carl, 2015), in the following ways: as the course teacher I was trained in the theory of constructive alignment through two five-credits courses in university pedagogy; the course described here is the fourth course I have taught at the university using constructive alignment; the contents of the course relating to entrepreneurial education were planned and discussed with experts in the field; the sections of the course dealing with intended learning outcomes, teaching and learning activities, and evaluation were discussed with experts in the theory of constructive alignment.

\section{Results}

The results relating to learning outcomes were triangulated (Baartman et al., 2007; Ravitch and Carl, 2015) and analysed both quantitatively and qualitatively.

Quantitative analysis was undertaken in relation to the 29 students (out of 35) who took the GET2 test at the beginning and at the end of the course. Given the type of data, the test 
used here is non-parametric and conservative, a Wilcoxon signed test for paired samples. Table I shows the result.

The analysis reveals a highly statistically meaningful change in the overall score $(p<0.01)$, a statistically meaningful change in risk taking and locus of control $(p<0.05)$, and quasi meaningful change in relation to the need for self-realisation. In the GET2 test, the need for autonomy is the only scale composed of only six questions (the others having 12), and this may have led to lower levels of variance and therefore non-meaningful results.

For the purposes of qualitative analysis, I selected the sections of the students' reflective journals commenting on and evaluating the course, which I found in 17 of the journals. Dialogical engagement gave rise to a two-step validation process with peer data analysis review sessions and participant validation strategies (Ravitch and Carl, 2015). First, together with two educational researchers, I undertook recursive reading of the anonymized feedback to vet themes. This data analysis was carried out individually with a view to identifying the main themes from the students' point of view, thus taking an etic perspective. We then met and discussed our results, agreeing upon a few themes. Second, I met with three course participants (a PhD exchange student in education and two of the most critical students) and I discussed with them the results of the qualitative analysis and any themes that emerged to ascertain their views.

The analysis is shown in Appendix 2, and reveals five themes:

(1) The course differs from the other university courses in that it is action based.

(2) The course allowed the students to acquire a broad concept of entrepreneurship.

(3) The course had generated a positive attitude towards entrepreneurship.

(4) The course made the students reflect on who they are, and who they want to become, in terms of their studies and their life in general.

(5) The course should have taken a more critical stance towards entrepreneurship.

As Appendix 3 shows, the response of St8 is particularly interesting as this student linked the learning outcomes directly with what he thought he had learnt.

\section{Discussion}

In parallel with the response of St8, who connected the intended learning outcomes of the course with his experience of the course, this section links the qualitative and quantitative analysis undertaken with the theory of constructive alignment and the sense of initiative and entrepreneurship, connecting the participants' perspectives with the theory, and seeking a synthesis between etic and emic perspectives (Ravitch and Carl, 2015).

The first theme to emerge was that the course differs substantially from other university courses by being action based. There is a clear connection between this theme and the teaching and learning activities designed to reach the desired learning outcomes, in particular the second intended learning outcome which is to apply entrepreneurship. This first theme suggests that the course is constructively aligned, as recommended by Biggs (2014). The teaching and learning activities were designed to prompt learners to turn

\begin{tabular}{lcccccc}
\hline & Self-realisation & Need for autonomy & Creativity & Risk taking & Locus of control & Overall \\
\hline$Z$ & -1.857 & -0.801 & -0.912 & -2.104 & -2.193 & -2.661 \\
$\begin{array}{l}\text { Asymp. } \\
\text { sig. (2 tales) }\end{array}$ & 0.063 & 0.423 & 0.362 & $0.035^{*}$ & $0.028^{*}$ & $0.008^{* *}$ \\
Notes: $n=29 . * p<0.05 ; * *<0.01$ & & & & &
\end{tabular}

Teaching a sense of initiative 
ideas into action, the very essence of a sense of initiative and entrepreneurship as defined by the European Commission (2007). The course was different from standard university courses based on lectures; it was group and action based with a degree of uncertainty. Participant validation confirmed this theme; the course was radically different from the usual lecture-based courses, and at the beginning the freedom and ambiguity in the tasks had given rise to conflict between them. By giving students the freedom to choose, the aim was to promote entrepreneurial attitudes such as autonomy and the taking of calculated risks. Students were in control of their own learning, demonstrating the student-centred nature of the course in line with research on andragogy and heutagogy (Forrest and Peterson, 2006; Jones et al., 2014; Penaluna and Penaluna, 2015).

The second theme was that the course allowed students to acquire a broad concept of entrepreneurship, which can be linked to the first intended learning outcome, namely the ability to explain the importance of a sense of initiative and entrepreneurship. The concept of entrepreneurship was broadened beyond business creation - everybody should be entrepreneurial in their life (Gibb, 2002). This theme suggests that the course had also an "about" approach, in other words it provided students with a basic understanding of the phenomenon of entrepreneurship. This confirms that "about" approaches are entry level-and therefore necessary - for entrepreneurial education, and can be combined with "through" methods, as indicated by Hytti and O'Gorman (2004). However, during participant validation, students suggested that they would have found it useful if they had been given more information about entrepreneurship at the beginning of the course. During validation students also connected this second theme with the fifth (see below).

The third theme was that the course generated a positive attitude towards entrepreneurship, with students considering self-employment as a viable option for their working life. This is reinforced by the meaningful difference between enterprising attitudes identified in the GET2 test at the beginning and at the end of the course. The generation of a positive attitude towards entrepreneurship (in most of the students, see the critiques below) was an unintended but desirable learning outcome, consistent with the theory: "constructively aligned teaching is not closed loop, focusing only on what is predetermined" (Biggs and Tang, 2011, p. 99). While Nabi et al. (2016) found that sometimes the outcomes of entrepreneurial education in higher education lead to a decrease in entrepreneurial intentions, this seems not to have been the case for the present study. The students understood the importance of being entrepreneurial as a lifelong pursuit. A further learning outcome consequent on the second and third themes is that of curiosity raising. Penaluna et al. (2010) suggested that to develop entrepreneurial knowledge skills and attitudes in students, constructivist paradigms need to build on curiosity and the subsequent discovery of solutions. Moreover, curiosity-led approaches can be pursued by first having the students engage in and actively participate in experiences, and then question what they have learnt (Penaluna et al., 2015). The relevance of questioning is highlighted in the fifth theme.

The fourth theme was that the course had encouraged the students reflect on who they were and who they wanted to become, in terms of their studies and their life in general. This can be related directly to the third intended learning outcome: reflecting on their own sense of initiative and entrepreneurship as part of their lifelong learning. Self-regulation and reflection are key to students' ownership of their learning processes in this context (Finsterwald et al., 2013; Klug et al., 2014; Wesselink et al., 2007). The students considered their learning from the perspective of their whole lives and thought about their goals and who they wanted to become, allowing entrepreneurship to be a possible option. This implies that they were connecting all of their experience, regardless of whether it originated from formal, informal or non-formal environments. During participant validation, students suggested that this had been the most valuable outcome of the course, as the career development plan made them think about their future. 
The fifth theme arising from the students' evaluation was a critique: the course did not present any criticisms of the concept of entrepreneurship. Participant validation linked this finding with the second theme: with greater knowledge "about" entrepreneurship, it might have been possible to link entrepreneurship to other concepts by the use of questioning. However, the students also conceded the following two points: first, their criticism had been based on a narrow view of entrepreneurship as business creation, which had in general been their "taken-for-granted assumption" when they enroled. This was partially because the teaching materials used (especially videos) and the GET test had led them think that the teacher had an uncritically positive view of entrepreneurship. However, it was still hard for them to fully understand the broad role of entrepreneurship in society: "educators often address this criticism of entrepreneurial education without noticing its role in transforming, not following, the current practices in society and economy" (Kyrö, 2015, p. 604). Second, a critical approach is typical of academic studies, and students of education therefore base their studies on critical pedagogy. St12, for example, writes "The demand for questioning and problematising is the fundamental character of academic thinking", while St17 contends, "my studies basically consist of critical sociology". Engaging in critical activity in this way leads to increased curiosity about entrepreneurship, as evidenced by Penaluna et al. (2015). While students in business schools or economics faculties are likely to display positive attitudes towards the entrepreneurial phenomenon, courses delivered in non-business faculties should consider offering diverse points of view (including criticism), thus taking into consideration the context in which they are being delivered (Jones et al., 2012).

\section{Conclusions}

This paper shows how a course on entrepreneurial education can be taught at tertiary level in faculties other than economics or business schools, as called for by many authors (Béchard and Grégoire, 2005; Gibb, 2002; Jones et al., 2014; Sarasvathy and Venkataraman, 2011). The objective was to explore entrepreneurial education beyond simply reflecting on activities: besides a reflective journal, students had to write a career development plan and undertake entrepreneurial activities at home. The course details learning outcomes, learning and teaching activities, and assessment, which have resulted in significant changes in attitudes towards a sense of initiative and entrepreneurship. Building on research on constructive alignment, this paper has concentrated on the effect of the course in terms of learning outcomes related to a sense of initiative and entrepreneurship, and presented an argument in favour of Biggs' $(2003,2012,2014)$ theory of constructively aligned courses. As shown by the GET test, the course focused on entrepreneurial attitudes such as initiative, autonomy, creativity and risk taking. Furthermore, in being allowed to choose their own broad types of entrepreneurial action, students could design their individual goals and, through their reflective journals, evaluate the extent to which they achieved them, giving students a degree of autonomy and self-determination as advocated by the andragogical approach (Jones et al., 2014; Penaluna and Penaluna, 2015).

This paper has explored the literature on teaching entrepreneurial education in tertiary education. It seems that most tertiary courses rely on "about" and "for" approaches to entrepreneurial education and, following the behaviourist and cognitive learning paradigms of knowledge transmission, are therefore based on a teacher-centred approach. In line with the literature (Robinson et al., 2016), "through" approaches to entrepreneurial education require a student-centred approach which has to be based on constructivism; one possible constructivist theory of course design is Biggs' theory of constructive alignment. Although the course was designed according to a "through" approach, enabling learners to have an entrepreneurial learning experience, in the process students gained an understanding of the entrepreneurial phenomenon (the "about" approach). In other words, this paper suggests that "about" approaches can be arrived by means of "through" approaches. Returning to
Teaching a sense of initiative 
ET

60,2

learning paradigms, this does not mean that a course should deploy a mix of active (constructivist) teaching methods and passive (behaviouristic or cognitive) approaches based on knowledge transmission, however. Both competence-based education (Baartman et al., 2007; Wesselink et al., 2007) and the theory of constructive alignment (Biggs and Tang, 2011) rely on constructivism, and feature a plurality of teaching and assessment methods to achieve the desired learning outcomes, which include knowledge.

In relation to the four scenarios set out by Jones et al. (2012) for higher education, this paper makes an argument in favour of the first scenario, entrepreneurship as a subject for all, a transformative experience capable of shaping the mindset of all who participate. However, each of the scenarios is highly dependent on the institution in question. This paper has looked at a standalone course that was delivered only once, and was driven by the goodwill of the researcher in the face of scepticism on the part of both faculty and students towards the concept of entrepreneurship. Much work is still needed to help education faculties understand that a sense of initiative and entrepreneurship is of value to everyone, and in particular to the educators of the future.

\section{Limits of the research}

The number of participants in the course was limited to 35 students. Data analysis was based on the 29 students who took the GET2 test at the beginning and at the end of the course, and the 17 students who provided feedback on the course in their reflective journals. The GET2 test was administered directly in English without being adapted to Finnish culture, which may have given rise to bias in responses. The period between test and retest was only two months, which may have caused a memory effect.

\section{Acknowledgements}

This project received funding from the European Union's Horizon 2020 research and innovation programme under Marie Skłodowska-Curie Grant Agreement No. 654101. The author would like to thank Max Costa of Ca' Foscari and Paula Kyrö of Aalto University for their suggestions on the desirable structure and content of a course on entrepreneurial education; Heidi Hyytinen and Sary Lindon Bloom of Helsinki University for their advice on constructive alignment; Cybele Mcneil and Sarah Rimmington for proof-reading; Paula Kyrö for her lecture on the entrepreneurial method that impressed the students so much; Heidi Hyytinen and Terhi Esko of University of Helsinki for the joint data session; and the four students who took the course on an earlier occasion, and offered their reflections to validate the findings.

\section{Note}

1. To ensure authenticity, student comments have been extracted verbatim from feedback provided in reflective journals. N.B. (not all) students were native English speakers.

\section{References}

Baartman, L.K., Bastiaens, T.J., Kirschner, P.A. and van der Vleuten, C.P. (2007), "Evaluating assessment quality in competence-based education: a qualitative comparison of two frameworks", Educational Research Review, Vol. 2 No. 2, pp. 114-129.

Béchard, J.P. and Grégoire, D. (2005), "Understanding teaching models in entrepreneurship for higher education”, in Kyrö, P. and Carrier, C. (Eds), The Dynamics of Learning Entrepreneurship in a Cross-Cultural University Context, Research Center for Vocational and Professional Education, Faculty of Education, University of Tampere, Tampere, pp. 104-134. 
Biggs, J. (2003), "Aligning teaching and assessing to course objectives", Teaching and Learning in Higher Education: New Trends and Innovations, pp. 13-17, available at: www.researchgate.net/ profile/John_Biggs3/publication/241251310_Aligning_teaching_and_assessing_to_course_ objectives/links/5406ffe80cf23d9765a82d5a.pdf (accessed 21 December 2017).

Biggs, J. (2012), "What the student does: teaching for enhanced learning”, Higher Education Research \& Development, Vol. 31 No. 1, pp. 39-55.

Biggs, J. (2014), “Constructive alignment in university teaching”, HERDSA Review of Higher Education, Vol. 1 No. 1, pp. 5-22.

Biggs, J. and Tang, C. (2011), Teaching for Quality Learning at University. What the Student Does, McGraw-Hill, New York, NY.

Blenker, P., Korsgaard, S., Neergaard, H. and Thrane, C. (2011), "The questions we care about: paradigms and progression in entrepreneurship education", Industry and Higher Education, Vol. 25 No. 6, pp. 417-427.

Blenker, P., Trolle Elmholdt, S., Hedeboe Frederiksen, S., Korsgaard, S. and Wagner, K. (2014), "Methods in entrepreneurship education research: a review and integrative framework", Education + Training, Vol. 56 Nos 8/9, pp. 697-715.

Caird, S. (1990), "What does it mean to be enterprising?", British Journal of Management, Vol. 1 No. 3, pp. 137-145.

Caird, S. (1991), "Testing enterprising tendency in occupational groups", British Journal of Management, Vol. 2 No. 4, pp. 177-186.

Cromie, S. (2000), "Assessing entrepreneurial inclinations: some approaches and empirical evidence", European Journal of Work and Organizational Psychology, Vol. 9 No. 1, pp. 7-30.

European Commission (2007), European Competences for Lifelong Learning, Publication Office of the European Union, Luxembourg.

Fayolle, A. (2013), "Personal views on the future of entrepreneurship education", Entrepreneurship \& Regional Development, Vol. 25 Nos 7-8, pp. 692-701.

Fayolle, A. and Gailly, B. (2008), "From craft to science: teaching models and learning processes in entrepreneurship education", Journal of European Industrial Training, Vol. 32 No. 7, pp. 569-593.

Fiet, J.O. (2001), "The pedagogical side of entrepreneurship theory", Journal of Business Venturing, Vol. 16 No. 2, pp. 101-117.

Finsterwald, M., Wagner, P., Schober, B., Lüftenegger, M. and Spiel, C. (2013), "Fostering lifelong learning - evaluation of a teacher education program for professional teachers", Teaching and Teacher Education, Vol. 29, pp. 144-155.

Forrest, S.P. and Peterson, T.O. (2006), "It's called andragogy", Academy of Management Learning \& Education, Vol. 5 No. 1, pp. 113-122.

Gibb, A. (2002), "In pursuit of a new 'enterprise' and 'entrepreneurship' paradigm for learning: creative destruction, new values, new ways of doing things and new combinations of knowledge", International Journal of Management Reviews, Vol. 4 No. 3, pp. 233-269.

Glaser, R. (1991), "The maturing of the relationship between the science of learning and cognition and educational practice", Learning and Instruction, Vol. 1 No. 2, pp. 129-144.

Hytti, U. and O'Gorman, C. (2004), "What is 'enterprise education'? An analysis of the objectives and methods of enterprise education programmes in four European countries", Education+ Training, Vol. 46 No. 1, pp. 11-23.

Jones, B. and Iredale, N. (2014), "Enterprise and entrepreneurship education: towards a comparative analysis", Journal of Enterprising Communities: People and Places in the Global Economy, Vol. 8 No. 1, pp. 34-50.

Jones, C., Matlay, H. and Maritz, A. (2012), "Enterprise education: for all, or just some?", Education+ Training, Vol. 54 Nos 8/9, pp. 813-824.

Jones, C., Matlay, H., Penaluna, K. and Penaluna, A. (2014), "Claiming the future of enterprise education”, Education + Training, Vol. 56 Nos 8/9, pp. 764-775.

Teaching a sense of initiative 
ET

60,2

Kirby, D.A. (2004), "Entrepreneurship education: can business schools meet the challenge?”, Education + Training, Vol. 46 Nos 8/9, pp. 510-519.

Klug, J., Krause, N., Schober, B., Finsterwald, M. and Spiel, C. (2014), "How do teachers promote their students' lifelong learning in class? Development and first application of the LLL interview", Teaching and Teacher Education, Vol. 37, pp. 119-129.

Kyrö, P. (2005), "Entrepreneurial learning in a cross-cultural context challenges previous learning paradigms", in Kyrö, P. and Carrier, C. (Eds), The Dynamics of Learning Entrepreneurship in a Cross-Cultural University Context. Entrepreneurship Education Series, Research Center for Vocational and Professional Education, Faculty of Education, University of Tampere, Tampere, pp. 68-102.

Kyrö, P. (2015), “The conceptual contribution of education to research on entrepreneurship education”, Entrepreneurship and Regional Development, Vol. 27 Nos 9-10, pp. 599-618.

Kyrö, P. and Carrier, C. (2005), "Entrepreneurial learning in universities: bridges across borders", in Kyrö, P. and Carrier, C. (Eds), The Dynamics of Learning Entrepreneurship in a Cross-Cultural University Context, Research Center for Vocational and Professional Education, Faculty of Education, University of Tampere, Tampere, pp. 14-43.

Lackeus, M. (2015), "Entrepreneurship in education: what, why, when, how. Entrepreneurship360", background paper, available at: www.oecd.org/ (accessed 6 October 2017).

Macht, S.A. and Ball, S. (2016), “'Authentic alignment' - a new framework of entrepreneurship education", Education + Training, Vol. 58 No. 9, pp. 926-944.

Mwasalwiba, E.S. (2010), "Entrepreneurship education: a review of its objectives, teaching methods, and impact indicators", Education + Training, Vol. 52 No. 1, pp. 20-47.

Nabi, G., Walmsley, A., Liñán, F., Akhtar, I. and Neame, C. (2016), "Does entrepreneurship education in the first year of higher education develop entrepreneurial intentions? The role of learning and inspiration", Studies in Higher Education, pp. 1-16.

Penaluna, A. and Penaluna, K. (2015), "Thematic paper on entrepreneurial education in practice. Part 2: building motivation and competencies", available at: www.oecd.org/ (accessed 24 October 2017).

Penaluna, A., Coates, J. and Penaluna, K. (2010), "Creativity-based assessment and neural understandings: a discussion and case study analysis", Education+ Training, Vol. 52 Nos 8/9, pp. 660-678.

Penaluna, K., Penaluna, A., Usei, C. and Griffiths, D. (2015), "Enterprise education needs enterprising educators: a case study on teacher training provision", Education + Training, Vol. 57 Nos 8/9, pp. 948-963.

Pittaway, L. and Edwards, C. (2012), "Assessment: examining practice in entrepreneurship education”, Education + Training, Vol. 54 Nos 8/9, pp. 778-800.

Quality Assurance Agency (QAA) (2012), Enterprise and Entrepreneurship Education: Guidance for UK Higher Education Providers, The Quality Assurance Agency for Higher Education, Gloucester, available at: www.qaa.ac.uk/ (accessed 24 October 2017).

Rasmussen, A. and Nybye, N. (2013), "Entrepreneurship education: progression model”, available at: www.ffe-ye.dk/ (accessed 24 October 2017).

Ravitch, S.M. and Carl, N.M. (2015), Qualitative Research: Bridging the Conceptual, Theoretical, and Methodological, Sage, Los Angeles, CA.

Robinson, S., Neergaard, H., Tanggaard, L. and Krueger, N.F. (2016), "New horizons in entrepreneurship education: from teacher-led to student-centered learning", Education+ Training, Vol. 58 Nos 7/8, pp. $661-683$.

Sagar, H. (2015), "Thematic paper on entrepreneurial schools. Part 2: entrepreneurial learning environments and a changed role for teachers", available at: www.oecd.org/ (accessed 24 October 2017).

Sarasvathy, S.D. and Venkataraman, S. (2011), "Entrepreneurship as method: open questions for an entrepreneurial future", Entrepreneurship Theory and Practice, Vol. 35 No. 1, pp. 113-135. 
Solomon, G. (2007), "An examination of entrepreneurship education in the United States", Journal of Small Business and Enterprise Development, Vol. 14 No. 2, pp. 168-182.

Stormer, F., Kline, T. and Goldenberg, S. (1999), "Measuring entrepreneurship with the general enterprising tendency (GET) test: criterion-related validity and reliability", Human Systems Management, Vol. 18 No. 1, pp. 47-52.

von Glasersfeld, E. (1995), “A constructivist approach to teaching”, in Steffe, L.P. and Gale, J. (Eds), Constructivism in Education, Lawrence Erlbaum, Hillsdale, NJ, pp. 3-15.

Wang, X., Su, Y., Cheung, S., Wong, E. and Kwong, T. (2013), “An exploration of Biggs' constructive alignment in course design and its impact on students' learning approaches", Assessment and Evaluation in Higher Education, Vol. 38 No. 4, pp. 477-491.

Wesselink, R., Biemans, H.J., Mulder, M. and Van den Elsen, E.R. (2007), "Competence-based VET as seen by Dutch researchers", European Journal of Vocational Training, Vol. 40 No. 1, pp. 38-51.

\section{Appendix 1}

\begin{tabular}{|c|c|c|c|c|c|c|}
\hline Grade criterion & 0 & 1 & 2 & 3 & 4 & 5 \\
\hline $\begin{array}{l}\text { Readability of the } \\
\text { text Structure }\end{array}$ & $\begin{array}{l}\text { Not } \\
\text { submitted }\end{array}$ & $\begin{array}{l}\text { Unclear } \\
\text { unstructured }\end{array}$ & $\begin{array}{l}\text { In } \\
\text { between } \\
1 \text { and } 3\end{array}$ & $\begin{array}{l}\text { A further round of } \\
\text { reviews would be } \\
\text { needed to address } \\
\text { flaws Structure } \\
\text { requires improvement }\end{array}$ & $\begin{array}{l}\text { In } \\
\text { between } \\
3 \text { and } 5\end{array}$ & $\begin{array}{l}\text { The text is easy } \\
\text { to read and well } \\
\text { structured }\end{array}$ \\
\hline $\begin{array}{l}\text { Consistency with } \\
\text { the sense of } \\
\text { initiative and } \\
\text { entrepreneurship } \\
\text { "turning ideas } \\
\text { into action" }\end{array}$ & & $\begin{array}{l}\text { Not stated, } \\
\text { confused, the } \\
\text { assignment } \\
\text { is not daring } \\
\text { enough or is } \\
\text { unrealistic }\end{array}$ & & $\begin{array}{l}\text { Partially } \\
\text { undeveloped. } \\
\text { Assignment could be } \\
\text { slightly more daring } \\
\text { or is sometimes } \\
\text { unrealistic }\end{array}$ & & $\begin{array}{l}\text { The homework } \\
\text { assignment is } \\
\text { appropriate to the } \\
\text { development } \\
\text { (flourishing) of } \\
\text { the individual: it } \\
\text { is both daring } \\
\text { and feasible }\end{array}$ \\
\hline $\begin{array}{l}\text { Level of analysis } \\
\text { of idea/initiative }\end{array}$ & & $\begin{array}{l}\text { Idea or } \\
\text { initiative not } \\
\text { developed }\end{array}$ & & $\begin{array}{l}\text { Another round of } \\
\text { reviews would be } \\
\text { necessary to see the } \\
\text { idea or initiative well } \\
\text { developed }\end{array}$ & & $\begin{array}{l}\text { Idea or initiative } \\
\text { is well developed }\end{array}$ \\
\hline
\end{tabular}

Teaching a sense of initiative

\section{Appendix 2. Analysis of students' reflective journals and main themes emerging[1]}

(1) The course differs from the other university courses in that it is action based.

St4: "The home and group activities were helpful, and I learned from them quite a lot. I did enjoy the fact that the course was so hands-on".

St5: "The overall feeling of the course was that it was different from the rest of the rather theoretical courses we usually have at the university. I liked the tasks and the workgroup".

St8: "Regarding the general organising of the course now nearing its end, I would definitely say that there has been strong encouragement towards finding your own way of putting the presented ideas into action. Whether the goal is to foster our own entrepreneurial capabilities or to develop our readiness to transfer it to others, getting familiar with the practical aspect is important".

St9: "My group, all other students and the teacher have changed the idea of a university course with this creative way of working and sharing".

St10: "Overall, this course was a little bit different than others, but it was also fun". 
ET

60,2

(2) The course enabled the students to acquire a broad concept of entrepreneurship.

St3: "I think the course makes you understand what entrepreneurship is and how you can use it in your personal life and studies".

St4: "The ideas behind entrepreneurship education have merit, and they are quite interesting and useful".

St5: "Anyways I am happy to have chosen this course and gotten a glimpse on what entrepreneurship education is all about".

St6: "I think that my thoughts towards entrepreneurship have changed during the course. Before, entrepreneurship has (sic) a distinct field for me".

St8: "Explicitly we learned about the key competences and the importance that entrepreneurship education has regarding individual and societal-level transformations".

St15: "I have gotten a lot of new information about entrepreneurship education and entrepreneurial mindset, which is very refreshing":

(3) The course generated a positive attitude towards entrepreneurship.

St2: "For a long time I've never thought of myself as an Entrepreneur but the happenings during these past two years have opened my mind and made me think of it more positively than before".

St3: "I am more entrepreneurial than I first thought, if I only dared a bit more and took more risks. I perhaps didn't get all the answers I wanted, about how to use an entrepreneurial way of thinking in your teaching, even though the subject was touched upon by the guest's lecture".

St6: "I thought that it was too risky and very hard work to be an entrepreneur. During the course, I have learned how entrepreneurship includes the terms affordable risk, networks, effectuation etc. and it does not sound that terrifying anymore. The course has made me think about entrepreneurship as an option, not as a field that I have to avoid".

St9: "During the course I have collected tools for passing on my enthusiasm of entrepreneurship education".

St10: "In this course I have learnt a lot more of (sic) entrepreneurship mindset. Even though I think I won't become an entrepreneur, I can see myself working in a start-up company in the future. This course thought me to remember (sic) that anyone can become an entrepreneur and an entrepreneur can be just a normal person with a good idea. An entrepreneur doesn't have to be a superhero".

St13: "I think I am more open to new ideas and it is even possible someday that I can start my own business".

St14: "Actually, my total score has increased, and my self-confidence, responsibility and courage also has given me the motivation I needed to jump out (sic) the sofa and start some new projects. I will make a great effort to make from this course, a real change in my life and not words in deaf ears".

St15: "All in all this has been an eye-opener for me. From now on I'm going to be more alert and take more action and not be afraid of failure!"

St17: "I find entrepreneurship education an interesting opening in our field and I am definitely taking what I have learned, initiative and entrepreneurism, into action!":

(4) The course made the students reflect on who they are and who they want to become in terms of their studies and their life in general.

St1: "This course also helped me clarifying myself (sic), I had to think about my future and my goals and that has been helpful to me. Being in this class also made me see more views of 
interpreting my reality, and helped me discovering (sic) myself. I want to thank you for this introspective journey and for all the challenges that I made (sic) from this subject. It's always good and fun learn different things that will be useful in the future".

St3: "During this course I have discovered a lot about myself and my way of thinking".

St7: "During my home action, I had the possibility to reflect the education I am involved in, and I am now going to make some changes".

St8: "Implicitly, I would argue that each one of the discussed subjects are important in learning, educating and developing yourself or others".

St9: "The warm atmosphere and the reflective style of discussion are invaluable tools, and I am going to use them. My personal findings during this course have important implications for my future".

St10: "This course also thought me more about myself and I think the GET2 test was fun even though many answers could vary depending of the situation".

St11: "I liked the tasks and actions we had to do. They make me think about my career plans and my identity as an educationist. I really had to put myself on the line and to make my thoughts 'visible'. So the reflection part of the course was excellent. Even I felt many (sic) internal conflicts during this course, this really put (sic) me thinking. And the thinking is the key of learning. And that is something that can never be wrong".

St13: "I see some positive changes after the course. I have learned to analyse myself and identify my skills and abilities. I have a clearer future/career plan written down. I think I learnt a lot just by reading others' writings. I am very happy with the results".

St16: "This course has most definitely initiated a reflective journey within myself but also in a broader context of school and work. I am happy that I, in a sense, was forced to reflect upon my own life and self, this led to a lot of self-development which might not have happened otherwise. Also all the discussions and reflections within the group generated new thoughts and ideas around studies and working life":

(5) The course should have taken a more critical stance towards entrepreneurship.

St5: "We could for example have been in groups and thought of alternative more entrepreneurial ways of teaching or critically looked at the educational system and find new solutions to existing problems".

St12: "I found myself (sic) was rather unconvinced and to be honest at some point unmotivated in this course because it seemed that the ideology behind entrepreneurship and the critique was not discussed or in fact even acknowledged".

St17: "My essay's appearance is very negative, but I do not want you to think that this is my final judgement or even overall judgement to this subject now. I wanted to take a critical stance, which I felt was missing in the course and when I took that course of action I found it impossibly difficult to change or develop my stance to a more positive approach, without losing the coherency of the text".

\section{Appendix 3. Part of St8's reflective journal}

It is interesting to compare my experience from the course to the official goals which were the following:

- explain why entrepreneurship is important;

- apply entrepreneurship education in your action; and

- reflect on the development of own sense of initiative and entrepreneurship.

My personal feeling is that at least my participation covered all of these subjects. The first point was covered both implicitly and explicitly. Explicitly we learned about the key competences and the importance that entrepreneurship education has regarding individual and societal-level transformations. Implicitly, I would argue that each one of the discussed subjects is important in learning, educating and developing yourself or others.

The second one of the official goals was well developed in the career development plan and in my case also the home action. Overall, I consider both of these activities have to do with being alert to
Teaching a sense of initiative 
possibilities, creating value and putting ideas into action. The last goal was met during the discussions that we had in the classroom as well as with this learning diary.

Regarding the general organising of the course now nearing its end, I would definitely say that there has been strong encouragement towards finding your own way, of putting the presented ideas into action. This seems to fit the topic very well. Models like the "Effectuation" seem very straight forward in manner and the most crucial part left to the person following these teachings is putting it all into practice. It is therefore very reasonable that this was also included into the study programme. Whether the goal is to foster our own entrepreneurial capabilities or to develop our readiness to transfer it to others, getting familiar with the practical aspect is important.

\section{Corresponding author}

Daniele Morselli can be contacted at: daniele.morselli@helsinki.fi 